\title{
Spiritual Psychotherapy and Mental Health: The Forgiveness Therapy in Achieving Spiritual Well-Being of Drug Addicts with Depression Disorders
}

\author{
Hielda Noviyanty ${ }^{1 *}$, Zainab Ismail ${ }^{2}$, Salasiah Binti Hanin Hamjah ${ }^{3}$, Abu Dardaa \\ Mohamad $^{4}$ \\ ${ }^{1}$ Centre for Human and Community Wellbeing, Faculty of Islamic Studies, Universiti Kebangsaan Malaysia, 43600 \\ BANGI, Selangor, Malaysia \\ ${ }^{2}$ Centre for Human and Community Wellbeing, Faculty of Islamic Studies, Universiti Kebangsaan Malaysia, 43600 \\ BANGI, Selangor, Malaysia. \\ ${ }^{3}$ Centre for Human and Community wellbeing, Faculty of Islamic Studies, Universiti Kebangsaan Malaysia, 43600 \\ BANGI, Selangor, Malaysia. \\ ${ }^{4}$ Centre for Human and Community Wellbeing, Faculty of Islamic studies, Universiti Kebangsaan Malaysia, 43600 \\ BANGI, Selangor, Malaysia. \\ Email: hieldahidayat86@gmail.com
}

\begin{abstract}
Emotions involve all the inner feelings experienced by each individual. Such as feelings of disappointment, sadness, anger, and annoyance which are expressions of feelings when someone is not well. This behavior is common and is carried out by everyone in social life. So there is the difficulty for most individuals in controlling themselves from these emotional feelings. And have an impact on the form of feelings of revenge, anti-social until depression. This is because each individual's fluctuating emotions are different. Self-difficulty in giving forgiveness to oneself or others, instead indirectly has damaged one's thinking and affect on spiritual well-being. There are still many people in society today who hate other people and do not forgive others. Even though without realizing it, this act causes hurt feeling in oneself and result in escape by abusing drugs. Therefore, strong negative feelings can even lead to depression. This study aims to (1) describe of forgiveness therapy for drug addicts who have depressive disorders, (2) describe the spiritual wellbeing of drug addicts with depressive disorders. This study used a descriptive qualitative method to explain the study in terms of the impact of forgiveness therapy. To collecting data the study using content analysis approach searching of Scopus, Clarivate, and Google Scholar. The results is found that there are a positive impression for the healing of drug addicts who experienced depression as well as affecting the spiritual well-being of patients. This study can also be applied by yourself with the guidance and support of the family.
\end{abstract}

Keywords: forgiveness therapy, spiritual well-being, drug addicts, mental health disorders, depression.

\section{INTRODUCTION}

The mistake is one thing that is always covering human life. This is because basically, humans are creatures that cannot be separated from making mistakes. Human life as a social being also shows that the attitude and character of each human being are different (Pentland, \& Andrew 1999;Reis, Collins \& Berscheid 2000;Reddy et al. 2017). Human social attitudes originate from the interactions that prevail in the community (Budijanto, Wan Ahmad, \& Komang Astina, 2015). When in social and interactions that occur there are differences, not only in attitudes and character but also in terms of ways of thinking and views of something around (Brookes et al. 2018;Reddy et al. 2017). The environment is one of the reasons that influence humans in shaping a person's character (Budijanto et al., 2015). Although the family environment has a big role in shaping a person's personality (Hamjah et al. 2014;Lahiji, \& Besharat 2019;Zakiei et al. 2020), but some changes shape human character to have negative traits, and intentionally or not sometimes humans hurt each other or hurt each other's heart and feelings. 
The need for tolerance mutual respect, respect for fellow humans as the basis of mutual forgiveness. This is to maintain social well-being between communities and also spiritual well-being a person (Toussaint, Webb, \& Hirsch, 2017). Social well-being in this study refers to a good relationship between humans so that it facilitates all activities that can affect the potential of social life. Especially in establishing good relationships with others in terms of religion, an economy, or culture. Meanwhile, spiritual well-being itself means serenity of the soul and the achievement of life goals (Gomez \& Fisher, 2003), free from emotional feelings (Bekelman et al., 2007) due to negative interactions in society.

Therefore, to maintain spiritual well-being in a person as a form of good social relations, mutual forgiveness is required (Toussaint et al., 2017). In this case, the recommendation to forgive is often found through advice or da'wah (Effendy \& Rustandi, 2020; Kadir et al., 2020;Surip, Razak, Tamuri, \& Fatah, 2019). Nevertheless, there is goodness in forgiving oneself or others. Especially the relationship with mental health which affects a person's physical health (Arslan, 2017). Mental health will experience problems when a person feels emotions and failure to control himself (Suhron, Yusuf, Subarniati, Amir, \& Zainiyah, 2020). This means that someone will find comfort for himself even by abusing drugs. Most adolescents to adults consume drugs without thinking about the impact that will be found on them (Soleimani \& Khaghani Esfahani, 2019). One of them in this study is experiencing mental health disorders as a result of addiction depression. The adverse impacts of unknowingly drug abuse have caused a person to experience depressive mental health disorders as a result of addiction (Martínez-Vispo, Martínez, López-Durán, Fernández del Río, \& Becoña, 2018). Therefore, in this study aims to explore the profiles of drug addicts and explore how forgiving therapies can work in treating drug addicts with depressive disorders.

\subsection{The Profile Of Drug Addicts Who Have Mental Health Depression Disorders.}

The profile of a drug addict is an important component of knowing the causes and reasons why a person is taking drugs. It is therefore easy to identify the level of severity of a person in taking drugs and identify drug addicts who suffer from mental health disorders, in this case namely depressive disorders. Drug addicts are individuals who are involved in drug abuse for a prolonged period so that they are addicted. Addiction can occur in any circle, even drug abuse has been done between adolescence and adulthood. This means that drug abuse has spread in all circles, and has been studied for a long time (Alexander, 2000). However, in this study, drug addicts are those who have experienced depressive disorders. Based on the period of use, relapse or drug use occurs in addicts who have been abusing drugs for a long time. This is similar with Syukri (2019) study which found that the use of drugs repeatedly, one of which is due to the duration of use for many years.
Meanwhile, damage to the nerves of the addict's brain and body occurs due to prolonged use (Amanda, Humaedi, \& Santoso, 2017). In addition, the impact on mental health problems is one of the reasons for long and recurring addiction (Zou et al., 2017). Most drug abuse in the past 5-10 years will experience depression or mood disorders (Sullivan, 2018).

The background of drug addicts based on previous studies occurs a lot of those who are still in adolescence between the ages of 15-39 years, according to the level of drug addiction education that applies to those who have a low level of education and do not even go to school. Furthermore, based on the type of work, most of them work as general workers. Drug addiction is found in many people living in rural areas. Additionally, the drug addict in this study was someone who took drugs over a long period of time and experienced episodic withdrawal symptoms (Nestler \& Lüscher 2019). This happens due to the type of drug used and even becomes medicine for his recovery, causing mental health problems, one of which is a depressive disorder. Likewise, drug addiction also occurs in people based on different backgrounds. In terms of education, according to Yahya Buntat (2009) many individuals do not attend school. Furthermore, based on the report (Agensi Anti Dadah Kebangsaan, 2017), cases of drug addiction to depression or mood disorders in Malaysia mostly occurred at SPM / SPMV academic graduation, seen from the figure reaching $32.57 \%$ of cases. This means that drug abuse can occur among people with low levels of education. In terms of the age according of Majumder et al. (2021) study that addiction, based on age in India applies to adolescents is so high that it reaches $42.9 \%$, mostly starting from the age of 21-30 years. Likewise in Malaysia in terms of age, addiction is widely used in adolescents between the ages of 20 and 39 (Ismail 2017).

Besides that, seeing the social status of drug addicts, usually drug use applies to the lower middle of society and most of them live in urban areas (Yahya Buntat, 2009). Likewise, drug use occurs due to the type of work that is considered to require drugs as a support at work (Sofin, Danker-hopfe, Gooren, \& Neu, 2017). Following the study of Yahya Buntat (2009), the type of work itself is the biggest victim of drugs after private work. In addition, reports from the Agensi Anti Dadah Kebangsaan (2017) mostly occur by laborers. In addition, based on the type of drug used, according to the Agensi Anti Dadah Kebangsaan (2017) methamphetamine is actually in great demand by drug addicts. Likewise, types of marijuana, but is used as a drug that can help in the medical field (Woodruff \& Shillington 2016).

\subsection{Depression on Drug addicts}

Mood disorders or depression are the mental health problem that becomes the main of problem that affects a person's mood so that got an erratic mood. This has an impact on emotional exhaustion such as feelings of 
sadness, feelings of worthlessness, neglect, and feelings of hopelessness. Likewise, mood disorders are usually related to sleep problems, eating disorders, feelings of self-blame without any cause (R. F. Ismail, Abd. Rashid, Abd. Wahab \& Ishak, 2019). As depressive symptoms can also be seen from the condition of frequent anger for no reason, frustration, and even thoughts of committing suicide (Kroning \& Kroning 2016). In fact, in a state of depression, these symptoms can also attract the patient to drug abuse (R. F. Ismail et al. 2019).

The effect of depression disorder can be experienced by adolescents and adults. Likewise, the main factors of depression include financial factors, traumatic disease, illness, work environment, and use of drugs (J. Chen et al. 2021). For many women, depression may also occur due to pregnancy and birth (Ningrum, 2017). And also A person's physical illness often causes depression (Donsu, Hadjam, Asdie \& Hidayat, 2014). In addition, for gold residents, the likelihood of gloomy disturbances has been predicted to increase with increasing time (Sivertsen, Bjørkløf, Engedal, Selbæk, \& Helvik, 2015). In fact, following medical comorbidities, gold residents have a high rate of depression and recurrence (Haigh et al. 2018; Mirkena et al. 2018).

Although Buckman's et al. (2019) study instead highlighted the level of seriousness of gloomy disorders due to failure in the treatment process undertaken by the patient due to lack of discipline or lack of attention from the patient. This situation can result in someone consuming drugs as a solution (Sullivan 2018). This means that attention is one of the factors that can help the recovery process for gloomy disorders from the family environment or the community environment (Salasiah Hanin Hamjah et al. 2012). This can be an effort to reduce depressive disorders in the community.

There have been many attempts to reduce depressive disorders as a recovery process for drug addicts who experience depression. This proves the importance of mental health in today's society. Types of treatment that are carried out range from medical to nonmedical, are complementary or traditional. This means treating from a physical to spiritual perspective for drug addicts who experience depressive disorders. As in China, traditional Chinese Medicine is performed for patients with depressive disorders by using herbal remedies as antidepressants to stimulate the nerves in the patients. (Li et al. 2020). Likewise, treatment with drugs is also carried out using ketamine as an antidepressant which is believed to have faster efficacy than other drugs on changes in patient behavior (Krystal et al. 2019).

The Krystal et al. (2019) study explained that treatment using antidepressants either in the form of herbs or drugs have been introduced for a long time but therefore there is a disorder in the body of patient, it is due to epigenetic changes of the patient. Yet antidepressants work only for short periods, so other studies highlight the presence of efficacy that can affect patients 'cognitive to get a good mood, meaning a decrease in depressive episode disorders using electroconvulsive therapy (Mathew et al. 2019). But this therapy has limitations due to the stigma of society, there is fear as a result of side effects so that it is less applied by patients. Drug addicts who suffer from depressive disorders have suffered from disability either physically or spiritually, therefore spiritual treatment is needed that can help the patient's recovery process.

\subsection{The Effects Of Self-Forgiving Therapy On Drug Addicts Suffering From Depressive Disorders}

Forgiveness in Islam is written as al 'afw. In the Quran, the word al 'afw is even written 34 times, 7 of which discusses forgiveness (Khasan, 2017). According to Khasan (2017) on the other hand, behind the word al 'afw, when it is muta'addih, it has the meaning of forgiving, and when it is used, it becomes lost. This means as according to Bahtiar (2009) that by forgiving oneself as well as others means having lost the guilt that once existed. Forgiveness is a psychological element of the Quran, one of the parts of Sufi psychotherapy that affects the psyche of every human being (Rohimin, 2019), also included in spiritual psychotherapy (Ahmad Rusydi, 2015). Forgiveness therefore has a powerful influence on one's peace of mind in better life.

Forgiveness, on the other hand, has meaning as an effort to remove hurt feelings and open one's heart to accept every mistake as a lesson in the future. In real life, everyone has a social role in life (Kong, Gong, Sajjad, Yang, \& Zhao, 2019). This creates a habit of people to interact with each other (An, Jung, \& Lee, 2019). In fact, it has become common if there are misunderstandings or problems with each other. So basically every human being has patience according to the mental ability he possesses. This is very important when they disagree with each other. Thus the fruit of patience is forgiveness.

The process of forgiveness is also a willingness to forget and leave all the negative things that affect the heart and feelings to cultivate hatred and resentment towards others (Enright \& Martin 2003). Sutton (2018) study of forgiving according to Worthington's theory focused on emotional exchange. This means negative emotions where a person cannot forgive can be changed with positive emotions which mean forgiveness. While there are two dimensions in the process of forgiving, namely intrapsychic (self -forgiveness) and interpersonal (forgiving others) (Khasan, 2017). Therefore, in obtaining and doing forgiveness, it certainly takes time and preparation to be able to go through the process.

As the process of forgiveness/forgiveness requires encouragement and readiness in oneself to confess all sins and mistakes that have been committed before (Akhtar \& Barlow 2018). The need for self preparedness means that the patient must be aware of his or her mistakes so that he or she can forgive himself or 
herself first. Forgiveness is not an easy thing to do and live. Some studies also highlight the lack of awareness to forgive oneself resulting in severe mental health disorders (Chung, 2016). Whereas psychologically, forgiveness can cultivate a sense of calm, and keep the patient from aggressive behavior and the severity of his mental health disorders (Kane, Jacobs, \& Sherman, 2019).

\subsection{It is good to forgive oneself and others for addicts}

Many studies highlight the effects of forgiving therapy either for oneself or for others. This is because forgiveness is one of the causes of restlessness that raises the issue of confusion in society. As Reed and Enright (2006) study highlight the impact of forgiving therapy performed and applied to patients with the mental health disorder such as deperession, anxiety disorders, and posttraumatic stress as victims of mental or emotional abuse, experiencing significant positive changes despite taking time in recovery.

In physical terms, forgiving therapy is influence the quality of life of a person with hemodialysis as well as the health of patients who are increasingly showing recovery (Ye et al., 2019). Similarly, forgiving therapy can help patients reduce emotions that lead to anger (Wijaya \& Widiyastuti 2020). This has to do with spirituality, where forgiving therapy becomes an adaptable treatment for a person with an addictive disorder (Charzynska, 2021).. Other studies have found a positive impact of forgiveness that can change a person's behavior caused by mental abuse such as bullying (Watson, Todorov, \& Rapee, 2020). Even forgiving therapy is effective for victims of emotional abuse (Ha, Bae, \& Hyun, 2019). As such, looking from several past studies sees benefits and priorities in forgiving behavior or with forgiving therapy treatments. Forgiving behavior can help ease the burden of everyone, in this case, a drug addict with depressive disorder. This therapy leads the drug addict to positive behavior and easily in undergoing healing to get well-being for the spiritual in him.

\subsection{Spiritual well -being of drug addicts suffering from a depressive disorder}

Spiritual well-being is one of the most important points in one's life to live a social life and as a religious being. This is because there is an attachment between man and God which is illustrated by the occurrence of a religious dimension and an existential dimension that is more of an emotional desire (Ellison, 1983). According to Musa, Pevalin and Al Khalaileh (2018), spirituality and religion can be applied to drug addicts suffering from depressive disorders as a treatment that is a source of strength in drug addicts. Similarly, spirituality and religion become a way to find the meaning and purpose of drug addicts who feel they have lost their self-esteem (Akbari \& Hossaini, 2018)

The study conducted by Noormohammadi et al. (2017) found that spirituality, in general, is the selfdefense of drug addicts to cope with the severity of a depressive disorder or depressive episode. This is because without a strong spirituality makes a person fragile so that he suffers from depression and drug use. This is in line with the study of Soylar and Dogan (2020) who examined the relationship of spiritual well-being with drug addicts, where drug use and the occurrence of depressive disorders due to spiritual weakness in a person. Spiritual effects not only mentality but also physically as inherent from spiritual well-being (Hashemi, Habibi, Sepahvand, \& Zadeh, 2019).

In addition, the impact of spiritual well-being is even able to prevent and be a solution to the problem of mental health disorders that lead patients to suicidal ideas or acts (Florez, Allbaugh, Harris, Schwartz, \& Kaslow, 2018). Spiritual can improve the quality of life of a person suffering from physical disease such as cancer (Zare, Bahia, Eidy, Adib, \& Sedighe, 2017), is effective in rehabilitation and treatment for patients infected with HIV (Hutson, Darlington, Hall, Heidel, \& Gaskins, 2018). Similarly, spirituality can increase the self-esteem of drug addicts (Khaledian, Pishvaei, \& Baghteyfouni, 2017). In fact with the existence of spiritual well-being for drug addicts who suffer from depressive disorders, making drug addicts able to control themselves. This is because there are significant changes both physically and spiritually. So drug addicts will gradually get out of the depression zone, this means they start to be able to control themselves not to take drugs until they stop using drugs.

\section{METHODOLOGY}

This study uses a qualitative descriptive method that can help clarify the profile of drug addicts who suffer from depressive disorders. According to Moeleong (2002) the process of collecting data from the meaning contained in writing. The research design used a content analysis study to show the effect of self-forgiveness therapy on the spiritual well-being of drug addicts with depression mental health problems. The data was obtained through searching the Scopus, Clarivate, and Google Scholar data bases.

\section{RESULT \& DISCUSSION}

\subsection{The effects of forgiving therapy}

Forgiveness therapy is a therapy done by a drug addict to be able to forgive the past, himself, and others who have destroyed his life. Forgiveness therapy in turn becomes one of the processes and stages of spiritual psychotherapy. This is because it is a psychological element of the Qur'an (Rohimin, 2019) the effect of 
forgiveness therapy for treating patients in terms of spirituality. Forgiveness therapy affects the healing process of drug addicts with depressive disorders. As the study of Peterson et al. (2017) advantages of effective forgiveness therapy for self-confidence to forgive and punish oneself. That is, forgiveness therapy has traced the process of achieving spiritual well-being. Similarly, a person will feel spiritual well-being in himself when applying forgiveness therapy to himself as well as others. As forgiveness therapy is able to improve the psychological well-being of a drug addict so that changes in behavior occur for the better (Singh \& Sharma, 2018). Therefore, in this study forgiveness therapy is the main factor for healing drug addicts because the healing process and the recovery process can take place quickly.

Forgiveness therapy according to the study of Uyun, Kurniawan, and Jaufalaily (2019) is carried out by confessing sins when praying after prayer. This is because performing the obligatory prayers is five times a day, not including other sunnah prayers. In fact a drug addict will more often remember his sins and also forgive sins or mistakes that have been made by others to him. But there is another way that drug addicts can forgive themselves and others, which is to pray before bed and forgive everyone around them and themselves. There is a reaction in the application of forgiving therapy, drug addicts are aware that there is peace, the heart feels light and relieved, there is a feeling of laziness to take drugs because peace of mind is felt. (Charzyńska, 2021).

\subsection{Spiritual Well -Being Drug Addicts}

The spiritual well -being of drug addicts who suffer from depressive disorders is a key factor in improving their quality of life. (Kurniawati, 2015). pleasure in living worship is felt by addicts after they get peace. That way the drug addict will find ease in living his life without taking drugs and suffering from depression. In Ellison (1983) view spiritual well-being is assessed as the relationship between man and God, which can lead man to the concept of obedience to God so that man remains in a good and quality life. The drug addict feels so close to his god that there is a dependence on continuing to pray. This study is in line with previous studies to obtain results from the concept of the spiritual well-being of drug addicts suffering from depressive disorders. Thus the statements from study participants about spiritual well -being, can return a person to the command of his god (Ying Chen et.al, 2019).

\section{CONCLUSION}

From several studies show that forgiving therapy has a positive effect. This effect has transformed drug addicts suffering from depression on the quality of life. Have a better desire for the future, and transform yourself into an acceptable person either in the outside environment or in the family environment. Thus forgiving therapy has a positive value for improving the spiritual well-being of drug addicts suffering from depression.

\section{REFERENCES}

[1] Agensi Anti Dadah Kebangsaan. (2017). Maklumat Dadah.

[2] Ahmad Rusydi. (2015). Kecemasan dan psikoterapi spiriual Islam. (M. A. Yaqin, Ed.) (1st ed.). Yogyakarta: Istana Publishing.

[3] Akbari, M., \& Hossaini, S. M. (2018). The relationship of spiritual health with quality of life, mental health, and burnout: The mediating role of emotional regulation. Iranian Journal of Psychiatry, 13(1), 22-31.

[4] Akhtar, S., \& Barlow, J. (2018). Forgiveness Therapy for the Promotion of Mental Well-Being: A Systematic Review and Meta-Analysis. Trauma, Violence, and Abuse, 19(1), 107-122. https://doi.org/10.1177/1524838016637079

[5] Alexander, B. K. (2000). The globalization of addiction. Addition Research, 8(6), 501-526.

[6] Amanda, M. P., Humaedi, S., \& Santoso, M. B. (2017). Penyalahgunaan Narkoba Di Kalangan Remaja (Adolescent Substance Abuse). Prosiding Penelitian Dan Pengabdian Kepada Masyarakat, 4(2), 339-345. https://doi.org/10.24198/jppm.v4i2.14392

[7] An, S., Jung, H., \& Lee, S. (2019). Moderating Effects of Community Social Capital on Depression in Later Years of Life: A Latent Interaction Model. Clinical Gerontologist, 42(1), 70-79. https://doi.org/10.1080/07317115.2018.1516263

[8] Arslan, G. (2017). Psychological maltreatment, forgiveness, mindfulness, and internet addiction among young adults: A study of mediation effect. Computers in Human Behavior, 72(February 2017), 57-66. https://doi.org/10.1016/j.chb.2017.02.037

[9] Bahtiar, A. (2009). Al-'afw dalam pemikiran alSyatibi dan Jamal al-Banna. Jurnal Sintesis, 3(1).

[10] Bekelman, D. B., Dy, S. M., Becker, D. M., Wittstein, I. S., Hendricks, D. E., Yamashita, T. E., \& Gottlieb, S. H. (2007). Spiritual well-being and depression in patients with heart failure. Journal of General Internal Medicine, 22(4), 470-477. https://doi.org/10.1007/s11606-006-0044-9

[11] Brookes, J., Warburton, M., Alghadier, M., MonWilliams, M., \& Mushtaq, F. (2018). Studying Human Behavior With Virtual Reality: The Unity Experiment Framework. BioRxiv, 455-463. https://doi.org/10.1101/459339

[12] Budijanto, Wan Ahmad, W. I., \& Komang Astina, I. (2015). Level of economic prosperity, social status and comfortable living of migrant workers in Tulungagung District, Indonesia. Mediterranean Journal of Social Sciences, 6(3), 282-286. https://doi.org/10.5901/mjss.2015.v6n3s2p282

[13] Charzynska, E. (2021). The effect of baseline patterns of spiritual completetion of an alcohok addiction. Journal of Religion and Health, 1-22.

[14] Chen, J., Liu, X., Wang, D., Jin, Y., He, M., Ma, Y., ... Hou, X. (2021). Risk factors for depression and anxiety in healthcare workers deployed during the 
COVID-19 outbreak in China. Social Psychiatry and Psychiatric Epidemiology, 56(1), 47-55. https://doi.org/10.1007/s00127-020-01954-1

[15] Chen, Y., Sion Kim Harris, Worthington, E. L., \& VanderWeele, T. J. (2019). Religiously or Spiritually-Motivated Forgiveness and Subsequent Health and Well-Being among Young Adults: An Outcome-Wide Analysis. Physiology \& Behavior, 14(5), 649-658. https://doi.org/10.1080/17439760.2018.1519591.R eligiously

[16] Chung, M. S. (2016). Relation Between Lack of Forgiveness and Depression: The Moderating Effect of Self-Compassion. Psychological Reports, 119(3), 573-585. https://doi.org/10.1177/0033294116663520

[17] Donsu, J. D., Hadjam, M. N. R., Asdie, A. H., \& Hidayat, R. (2014). Peran Faktor-faktor Psikologis terhadap Depresi pada Pasien Diabetes Mellitus Tipe 2. Jurnal Psikologi, 41(2), 241. https://doi.org/10.22146/jpsi.6953

[18] Effendy, D. I., \& Rustandi, D. (2020). The Identity Construction of Da'wah Leadership on Jama'ah Tabligh Movement. Ilmu Dakwah: Academic Journal for Homiletic Studies, 14(1), 145-162. https://doi.org/10.15575/idajhs.v14i1.9210

[19] Ellison, C. W. (1983). Spiritual well-being: Conceptualization and measurement. Journal of Psychology and Theology, 11(4), 330-338.

[20] Enright, R. D., \& Martin, A. D. (2003). Emotional Quality Management: Refleksi, revisi dan revitalisasi hidup melalui kekuatan emosi. Jakarta: Arga.

[21] Florez, I. A., Allbaugh, L. J., Harris, C. E., Schwartz, A. C., \& Kaslow, N. J. (2018). Suicidal ideation and hopelessness in PTSD: spiritual wellbeing mediates outcomes over time. Anxiety, Stress and Coping, 31(1), 46-58. https://doi.org/10.1080/10615806.2017.1369260

[22] Gomez, R., \& Fisher, J. W. (2003). Domains of spiritual well-being and development and validation of the Spiritual Well-Being Questionnaire. Personality and Individual Differences, 35(8), 1975-1991. 8869(03)00045-X

[23] Ha, N., Bae, S. M., \& Hyun, M. H. (2019). The effect of forgiveness writing therapy on posttraumatic growth in survivors of sexual abuse. Sexual and Relationship Therapy, 34(1), 10-22. https://doi.org/10.1080/14681994.2017.1327712

[24] Haigh, E. A. P., Bogucki, O. E., Sigmon, S. T., \& Blazer, D. G. (2018). Depression Among Older Adults: A 20-Year Update on Five Common Myths and Misconceptions. American Journal of Geriatric Psychiatry, 26(1), 107-122. https://doi.org/10.1016/j.jagp.2017.06.011

[25] Hamjah, S. H., Rasit, R. M., Samuri, M. A. A., Sham, F. M., Ismail, Z., \& Kusrin, Z. M. (2014). The role of the muslim family in dealing with adolescent Out-Of-Wedlock pregnancy.
Mediterranean Journal of Social Sciences, 5(29), 101-106.

https://doi.org/10.5901/mjss.2014.v5n29p101

[26] Hashemi, F. S., Habibi, M., Sepahvand, S., \& Zadeh, A. M. (2019). Presenting a Conceptual Model of Prevention of Substance Abuse in Adolescents Based on Spiritual Well Being: Qualitative Study. Journal of Arak University of Medical Sciences, 22(3), 129-147.

[27] Hutson, S. P., Darlington, C. K., Hall, J. M., Heidel, R. E., \& Gaskins, S. (2018). Stigma and Spiritual Well-being among People Living with HIV/AIDS in Southern Appalachia. Issues in Mental Health Nursing, 39(6), 482-489. https://doi.org/10.1080/01612840.2017.1423426

[28] Ismail, R. (2017). Pengaruh Faktor Individu, Keluarga dan Persekitaran Sosial Terhadap Tingkah Laku Penyalahgunaan Bahan dalam Kalangan Remaja. Akademika, 87(01), 7-16. https://doi.org/10.17576/akad-2017-8701-01

[29] Ismail, R. F., Abd. Rashid, R., Abd. Wahab, H., \& Ishak, Z. (2019). Simptom Kemurungan Dalam Kalangan Penagih Dadah Wanita Di Pusat Rawatan Dan Pemulihan Dadah. Journal of Nusantara Studies (JONUS), 4(2), 168-192. https://doi.org/10.24200/jonus.vol4iss2pp168-192

[30] Kadir, M. N. A., Ab Rahman, Z., Noor, A. Y. M., Kashim, M. I. A. M., Hamjah, S. H., Salleh, K., ... Ismail, S. (2020). Elements of management using the psychology of forgiveness during the covid 19 pandemic from an Islamic perspective. International Journal of Psychosocial Rehabilitation, 24(01), 5404-5411. https://doi.org/10.37200/IJPR/V24I1/PR200647

[31] Kane, M. N., Jacobs, R. J., \& Sherman, D. (2019). Forgiveness and gender between friends and coworkers. Journal of Spirituality in Mental Health, 21(1), $37-54$ https://doi.org/10.1080/19349637.2018.1437005

[32] Khaledian, M., Pishvaei, M., \& Baghteyfouni, Z. K. (2017). Effect of Islamic-based spiritual therapy on self- esteem and mental health of addicts. https://doi.org/10.18869/acadpub.jrh.7.2.719

[33] Khasan, M. (2017). Perspektif Islam dan psikologi tentang pemaafan. Jurnal At-Taqaddum, (1), 69-94.

[34] Kong, F., Gong, X., Sajjad, S., Yang, K., \& Zhao, J. (2019). How Is Emotional Intelligence Linked to Life Satisfaction? The Mediating Role of Social Support, Positive Affect and Negative Affect. Journal of Happiness Studies, 20(8), 2733-2745. https://doi.org/10.1007/s10902-018-00069-4

[35] Kroning, M., \& Kroning, K. (2016). Teen Depression and Suicide, A SILENT CRISIS. Journal of Christian Nursing: A Quarterly Publication of Nurses Christian Fellowship, 33(2), 78-86. https://doi.org/10.1097/CNJ.0000000000000254

[36] Kurniawati, H. (2015). Studi Meta Analisis Spiritual Well Being dan Quality Of Life. Seminar Psikologi \& Kemanusiaan, (2011), 978-979. 
Retrieved from https://media.neliti.com/media/publications/18358 9-ID-studi-fenomenologi-pengalaman-pasienkan.pdf

[37] Lahiji, L. A., \& Besharat, M. A. (2019). The role of personality traits in predicting family functioning and quality of life among nurses, Shiraz, Iran 20172018. Journal of Occupational Health and Epidemiology, $\quad 8(2), \quad 81-87$. https://doi.org/10.29252/johe.8.2.81

[38] Majumder, U., Das, J., Barman, S. C., Ghosh, J., \& Bhowmic, B. K. (2021). Sociodemographic and clinical profile of drug treatment seekers attending the State Psychiatric Hospital and Drug De.addiction Center at Agartala, Tripura. Indian Journal Psychiatry, 63.

[39] Martínez-Vispo, C., Martínez, Ú., López-Durán, A., Fernández del Río, E., \& Becoña, E. (2018). Effects of behavioural activation on substance use and depression: A systematic review. Substance Abuse: Treatment, Prevention, and Policy, 13(1), 1-13. https://doi.org/10.1186/s13011-018-0173-2

[40] Mirkena, Y., Reta, M. M., Haile, K., Nassir, Z., \& Sisay, M. M. (2018). Prevalence of depression and associated factors among older adults at ambo town, Oromia region, Ethiopia. BMC Psychiatry, 18(1), 1-7. https://doi.org/10.1186/s12888-018-1911-8

[41] Musa, A. S., Pevalin, D. J., \& Al Khalaileh, M. A. A. (2018). Spiritual Well-Being, Depression, and Stress Among Hemodialysis Patients in Jordan. Journal of Holistic Nursing, 36(4), 354-365. https://doi.org/10.1177/0898010117736686

[42] Nestler, E. J., \& Lüscher, C. (2019). The Molecular Basis of Drug Addiction: Linking Epigenetic to Synaptic and Circuit Mechanisms. Neuron, 102(1), 48-59. https://doi.org/10.1016/j.neuron.2019.01.016

[43] Ningrum, S. P. (2017). Faktor-Faktor Psikologis yang Mempengaruhi Postpartum Blues. Psympathic: Jurnal Ilmiah Psikologi, 4(2), 205218. https://doi.org/10.15575/psy.v4i2.1589

[44] Noormohammadi, M. R., Nikfarjam, M., Deris, F., \& Parvin, N. (2017). Spiritual well-being and associated factors with relapse in opioid addicts. Journal of Clinical and Diagnostic Research, 11(3), VC07-VC10. https://doi.org/10.7860/JCDR/2017/22819.9587

[45] Pentland, A., \& Andrew, L. (1999). Modeling and prediction of human behavior. Neural Computation, $11(1)$, 229-242. https://doi.org/10.1162/089976699300016890

[46] Reddy, S. M. W., Montambault, J., Masuda, Y. J., Keenan, E., Butler, W., Fisher, J. R. B., ... Gneezy, A. (2017). Advancing Conservation by Understanding and Influencing Human Behavior. Conservation Letters, 10(2), 248-256. https://doi.org/10.1111/conl.12252

[47] Reed, G. L., \& Enright, R. D. (2006). The effects of forgiveness therapy on depression, anxiety, and posttraumatic stress for women after spousal emotional abuse. Journal of Consulting and Clinical Psychology, 74(5), 920-929. https://doi.org/10.1037/0022-006X.74.5.920

[48] Reis, H. T., Collins, W. A., \& Berscheid, E. (2000). The relationship context of human behavior and development. Psychological Bulletin, 126(6), 844872. https://doi.org/10.1037/0033-2909.126.6.844

[49] Rohimin, R. (2019). Al-Qur'an Dan Psikoterapi Elaborasi Deduktif Dan Telaah Banding Pendekatan Tafsir Integratif Dalam Terapi Memaafkan Dan Meminta Maaf. Nuansa, 12(1), 112. https://doi.org/10.29300/nuansa.v12i1.2101

[50] Sivertsen, H., Bjørkløf, G. H., Engedal, K., Selbæk, G., \& Helvik, A. S. (2015). Depression and quality of life in older persons: A review. Dementia and Geriatric Cognitive Disorders, 40(5-6), 311-339. https://doi.org/10.1159/000437299

[51] Sofin, Y., Danker-hopfe, H., Gooren, T., \& Neu, P. (2017). Predicting Inpatient Detoxification Outcome of Alcohol and Drug Dependent Patients : The Influence of Sociodemographic Environment, Motivation , Impulsivity , and Medical Comorbidities, 2017.

[52] Soleimani, M., \& Khaghani Esfahani, M. (2019). The impact of network of social relationships effective in drug addiction and crime in connection with the it. Uct Journal of Social Science and Humanities Research, 2019(03), 37-41.

[53] Soylar, P., \& Dogan, U. (2020). The relationship between spiritual well-being and hopelessness levels of substance users. Medicine Science | International Medical Journal, 9(1), 186. https://doi.org/10.5455/medscience.2019.08.9163

[54] Suhron, M., Yusuf, A., Subarniati, R., Amir, F., \& Zainiyah, Z. (2020). How does forgiveness therapy versus emotion-focused therapy reduce violent behavior schizophrenia post restrain at East Java, Indonesia? International Journal of Public Health Science, $\quad 9(4), \quad 314-319$. https://doi.org/10.11591/ijphs.v9i4.20538

[55] Sullivan, M. D. (2018). Depression Effects on Long-term Prescription Opioid Use, Abuse, and Addiction. Clinical Journal of Pain, 34(9), 878884. https://doi.org/10.1097/AJP.0000000000000603

[56] Surip, N. A., Razak, K. A., Tamuri, A. H., \& Fatah, F. A. (2019). The Practice of Tolerance among Islamic Education Teachers (IETs) through \&lt;i\&gt;Shura\&lt;/i\&gt; in the Management of Da'wah Activities in Schools. Creative Education, 10(12), 2606-2614. https://doi.org/10.4236/ce.2019.1012188

[57] Sutton, G. W. (2018). Forgiveness : Psychological theory, research, and practice, (April).

[58] Syukri, M. (2019). Hubungan Jenis, Lama Pemakaian Dan Harga Diri Dengan Resiliensi Pengguna Napza Fase Rehabilitasi. Jambura Health and Sport Journal, 1(2), 41-47. https://doi.org/10.37311/jhsj.v1i2.2568

[59] Toussaint, L. L., Webb, J. R., \& Hirsch, J. K. 
(2017). Self-forgiveness and health: A stress-andcoping model. Handbook of the Psychology of SelfForgiveness. https://doi.org/10.1007/978-3-31960573-9_7

[60] Watson, H., Todorov, N., \& Rapee, R. M. (2020). Healing from Bullying in Early Adolescent Boys: The Positive Impact of Both Forgiveness and Revenge Fantasies. Journal of School Violence, 00(00), 1-14. https://doi.org/10.1080/15388220.2020.1858425

[61] Wijaya, Y., \& Widiyastuti, M. (2020). Forgiveness Therapy to Improve Subjective Well-being of Woman Victims of Sexual Harassment, (Icoh 2019), 257-260. https://doi.org/10.5220/0009592802570260

[62] Woodruff, S. I., \& Shillington, A. M. (2016). Sociodemographic and Drug Use Severity Differences Between Medical Marijuana Users and Non-Medical Users Visiting the Emergency Department, 385-391. https://doi.org/10.1111/ajad.12401

[63] Yahya Buntat, D. R. @ R. (2009). Profil penagihan dalam kalangan penagih yang di tahan di CRCC seluruh Malaysia. Agensi Antidadah Kebangsaan. Retrieved from https://www.adk.gov.my/wpcontent/uploads/3-ARTIKEL-PROFILPENAGIHAN-DAN-JENIS-KESALAHANUTM-min.pdf

[64] Ye, Y., Ma, D., Yuan, H., Chen, L., Wang, G., Shi, J., ... Jiang, X. (2019). Moderating Effects of Forgiveness on Relationship Between Empathy and Health-Related Quality of Life in Hemodialysis Patients: A Structural Equation Modeling Approach. Journal of Pain and Symptom Management, 57(2), 224-232. https://doi.org/10.1016/j.jpainsymman.2018.10.51 1

[65] Zakiei, A., Vafapoor, H., Alikhani, M., Farnia, V., \& Radmehr, F. (2020). The relationship between family function and personality traits with general self-efficacy (parallel samples studies). BMC Psychology, 8(1), 1-11. https://doi.org/10.1186/s40359-020-00462-w

[66] Zare, A., Bahia, N. J., Eidy, F., Adib, N., \& Sedighe, F. (2017). The relationship between spiritual wellbeing, mental health, and quality of life in cancer patients receiving chemotherapy. Journal of Family Medicine and Primary Care, 6(2), 169-170. https://doi.org/10.4103/jfmpc.jfmpc

[67] Zou, Z., Wang, H., d'Oleire Uquillas, F., Wang, X., Ding, J., \& Chen, H. (2017). Definition of substance and non-substance addiction. Advances in Experimental Medicine and Biology, 1010(November), 21-41. https://doi.org/10.1007/978-981-10-5562-1_2 